\title{
Religious Wars in the NDE Movement: Some Personal Reflections on Michael Sabom's Light \& Death
}

\author{
Kenneth Ring, Ph.D. \\ Kentfield, $C A$
}

\begin{abstract}
After a short personal glance at the early days of the field of neardeath studies, I offer an "open letter" to Michael Sabom in response to his book, Light \& Death (Sabom, 1998). This letter is in effect both a reply to certain criticisms Sabom has made of my work and an attempt to make public certain significant changes in my own view of near-death experiences (NDEs) since the publication of Heading Toward Omega (Ring, 1984), particularly in regard to their being a catalyst for higher consciousness. The second part of this essay presents a personal perspective on the ideological role of religion in the NDE movement, which I see as corrupting the original vision that prompted the formation of the field of near-death studies. I end with an ecumenical call for a return to the values of nontheologically driven inquiry with which near-death studies began.
\end{abstract}

Just a few days before sitting down to write this essay, I found myself in Florida with an old friend from the early days of near-death research and "the NDE movement," even before there was an International Association for Near-Death Studies (IANDS), a friend whom I had not seen for many years. John Audette is not a widely known name these days in NDE circles, but anyone familiar with the history of near-death research will know that without John's pioneering networking and zeal, the field of near-death studies and IANDS itself might never have come into being. It was John, for example, who first introduced Raymond Moody to Elisabeth Kübler-Ross, who then wrote the foreword to Moody's ground-breaking book, Life After Life (Moody, 1975). It was also John who almost single-handedly was responsible for directing the activities of the Association for the Scientific Study

Kenneth Ring, Ph.D., is Professor Emeritus of Psychology at the University of Connecticut. Reprint requests should be addressed to Dr. Ring at 19A Stadium Way, Kentfield, CA 94904. 
of Near-Death Phenomena, which was the immediate predecessor of IANDS, of which John then became the first Executive Director. And, finally, it was John who organized the very first meeting, in November of 1977, at the University of Virginia, of the initial band of researchers who would then join with Raymond Moody to create the field of neardeath studies and, a few years later, IANDS.

I was one of those whom John had recruited to come to that event, where in addition to Raymond Moody, I was to meet, among others, Bruce Greyson and Michael Sabom, both of whom were then already engaged, as I was, in some of the immediate post-Moody NDE research with which our field was to begin. And indeed, the five of us-Audette, Moody, Greyson, Sabom and I-were to remain in very close contact over the next few years and enjoyed a wonderful and warm fellowship as we plotted the course of our still nascent field of near-death studies and its organizational vehicle, IANDS.

Now, more than two decades later, sitting with John in Florida after so many years since we each had seen the other, it was natural for our conversation to wander back to those exciting beginning days and then to move forward into a consideration of the many changes the field of near-death studies has since undergone in the process of becoming a part of our popular culture, emerging as a kind of NDE movement with its own leading personalities, social dynamics, and contending missionary agendas. What we have today in the NDE movement, John and I agreed, was a far cry from either what we were or what we had envisaged in those early years. And to set the stage for the personal reflections to follow, it might be helpful here if I took a moment to give my own reading of who we were then and what kind of aims animated this original group of near-death researchers.

I use the noun "researchers" here quite deliberately because, essentially, that was how we principally regarded ourselves, I think. Moody, though not a trained researcher, had nevertheless unwittingly inaugurated our field by conducting the research for Life After Life, and the other four of us were either then or would shortly afterward be involved in carrying out our own investigations of NDEs. As for our consensual objectives, these were summed up quite straightforwardly in the name of the first NDE organization we founded, the Association for the Scientific Study of Near-Death Phenomena. As physicians, psychologists, and social scientists, we were primarily interested then in establishing the NDE's credentials as a valid phenomenon worthy of careful scientific investigation and scholarly concern. 
To be sure, all of us even then understood that in advocating the study of the NDE, we would be arousing and possibly threatening vested religious or spiritual interests and we were all aware that NDEs certainly had religious and spiritual import, but we did not band together either to serve or to undermine those institutions. Our own religious affiliations, or lack of them, varied, but they did not seem particularly relevant to something apparently so universal as the NDE, and I personally do not remember whether we even mentioned, much less discussed, our own religious or spiritual orientation at the time. Our concern was chiefly to put the NDE on the map by advocating its study, by conducting our own research, and by creating an organization that would further both.

Of us all, perhaps no one proved a better exemplar of what we sought to achieve than the cardiologist, Michael Sabom. An extremely careful and systematic researcher, Sabom's early book, Recollections of Death (Sabom, 1982), was a model of rigorous exploration of and incisive and objective commentary on the nature and significance of NDEs. And the meticulous work he reported in that volume is still often cited as providing the first compelling evidence for the authenticity of the NDE, namely, external corroboration for accurate and conventionally inexplicable visual perceptions during NDEs. After reading Sabom's book, I wrote a very laudatory review of it in IANDS' newsletter, Vital Signs (Ring, 1981), which was representative of the high favor it found in the then-emerging NDE community. And in John Gibbs' review of Sabom's recent book (Gibbs, 1999), written nearly 20 years after my review, he wrote that Recollections of Death still elicits deserved praise.

It is ironic, then, that it should be Sabom's latest book, the only one he has published since Recollections of Death, that so clearly reflects how far he now is, and perhaps how far many of us currently are, from the early ideals and goals that moved us to create the field of near-death studies in the first place. In fact, in a way, Sabom's two books, separated by the better part of two decades, together can well serve to illustrate the trend of things - and to my mind, it is an insidious one-in the NDE movement from those beginning days to the present moment where we stand on the edge of a new millennium.

Sabom's recent work-and how it is in some ways so decisively and disturbingly different in tone from his initial writings in the field-did much to trigger the kind of retrospectively-tinged discussion John and I held recently in Florida, and helped to stimulate some of the ideas for this essay. But from this point on, I would like to exempt John from the 
proceedings and offer my own views on why I find Sabom's new book, for all its considerable merits, nevertheless so deeply unsettling.

\section{A Personal Response to Light \& Death}

Since Gibbs has already provided a comprehensive review of Light \& Death (Gibbs, 1999), and one with which I largely concur, I would like instead to focus on some selected aspects of Sabom's book that have personal significance to me and that I find particularly troubling. And I would also ask the indulgence to frame this section of my essay differently, too, and make it more in the form of an extended letter to Sabom rather than an impersonal critique as such. The reason for this unusual request actually stems from a cordial letter that Mike, as I will now call him since we have been friends for years (and also because he sometimes refers to me by my first name in his book), wrote to me to accompany a copy of his new book. In it, he mentioned that in featuring chapters concerned with the work of several different near-death researchers, specifically, Moody, the cardiologist Maurice Rawlings, and me, that they "could just as well been titled, 'Letters to Ken, Raymond and Maurice' respectively" and were written in the hope of fostering "an open dialogue in the months and years to come regarding these matters" (M. Sabom, personal communication, November 4, 1998). It is thus in response to Mike's own invitation that I offer the comments to follow and present them in an epistolary form, which I hope will further the dialogue between us. So, in effect, this is "my letter to Mike."

To begin with, I want to tell you that there is much about your book I admire. On the whole, I read the first six chapters with a sense of real appreciation for both the quality of the case material you presented and the new ground your broke, particularly in regard to issues of faith, prayer, and healing in connection with the NDE. And I share with you the conviction that the case of Pam Reynolds, whose story you told so dramatically, is probably the single best instance we now have in the literature on NDEs to confound the skeptics and to thin the line to the vanishing point between near- and after-death experiences. Your bringing this extremely significant case to the attention of the NDE community is characteristic of you, too-and is still another seminal contribution you have made to this field. And I was of course pleased to see your making use of some of my own instruments in your work, such as the Life Changes Inventory, and reporting results on NDE aftereffects that very much squared with some of my earlier findings. 
All in all, it was clear to me on reading these chapters of your book that Light \& Death was, as your first book had been, another rich treasury of insights and findings for the NDE community as well as for the larger public concerned with this phenomenon.

Of course, it was not lost upon me, even in reading these chapters, that your own religious beliefs and commitments, which you later indicated have strengthened and deepened with the years since we were last in touch, would be brought to bear on your inquiry in a significant way. As you yourself pointed out early on, you had kept these pretty much out of the picture in Recollections of Death, but now you knew you had a commitment to honor and no longer conceal this important facet of your life and show its relevance to your work. All this, I must confess, gave rise to a certain disquiet as I read the first portion of your book. I knew before you were done that I would have to reckon with this, and see what I made of it.

I did not have to wait long because the very next chapter, which you significantly entitled "Church: Battleground for the NDE," was mostly about me, and it had an edge, a certain subtle animus, a tone of underlying innuendo that I found both surprising and unfair. Well, hear me out, Mike, and see if you can appreciate how this read from my point of view. At the least, I hope I can defend myself from some the charges you lay against me.

You started by recalling the occasion when John Audette (though you did not mention him by name) brought all of us near-death researchers together to meet Raymond Moody in Charlottesville in November, 1977. You got a few details wrong here-we did not all fly there, for example (I actually drove down from Connecticut with my then research assistant, Sue Palmer, and Bruce Greyson was still at the University of Virginia, and not the University of Michigan)-but these are mere cavils. One other error, though, seemed to be a little more revealing and possibly a bit pointed, in view of where you eventually went in this chapter.

I had noticed earlier in your book that you liked to employ certain novelistic touches, in the fashion of Michael Crichton, particularly at the beginning of your chapters, to heighten the dramatic effect of some of the cases you presented. Take, for example, the opening passages of your chapter on Pam Reynolds:

The Midas Rex whirlwind bone saw, rotating at a constant 73,000 rpm, was deftly held by the surgeon like a brush in the hand of an artist. A loud whirling noise, similar to that of a dentist's drill, filled the sterile air of the operating room.

Brain surgery was about to begin. (p. 37) 
Perhaps it was with something of the same stylistic flourish that when you came to describe meeting me, you presented this image to the reader: "Ken's full beard and long brown curly hair would have given him the appearance of an Old Testament prophet if it hadn't been for the blue jeans and brown penny loafers he was wearing at the time" (p. 132). Well, you got the clothes and the hair right, but actually I was beardless at the time (and I have a photograph to prove it, incidentally), as I still am. But given that you later represented me, rather like I understand Maurice Rawlings did in one of his books, as the prophet of "the Omega religion," I could not help reflecting afterward whether you had been already subtly preparing the reader for my later emergence as the would-be head of this faux religion.

In due course, however, you described my metamorphosis from a careful researcher to a man in search of the road to Omega who had apparently completely lost his scientific objectivity as he followed a kind of religious quest $\rightarrow$ or so you would have your readers believe. In discussing the research for my book, Heading Toward Omega (Ring, 1984), you correctly quoted some of my own statements concerning its methodological shortcomings and limitations, but you misrepresented it in other ways. For example, you claimed that I interviewed "a highly select group of 20 or so near-death experiencers" (p. 134). I do not know where you got that impression, Mike. First of all, there was nothing "highly selected" about the persons who comprised the interviewees for this research; they were just the people who happened to come to my attention at the time or who sought me out. As far as that goes, you never said how you selected your Atlanta sample of NDErs. Just as some NDErs may have come to my door and remained, as it were, to be interviewed, I assume you got yours in pretty much the same way. Random sampling procedures have never been exactly de rigueur in our field, as I am sure you would agree. Second, I actually interviewed 42 (not "20 or so") NDErs for this study - about the same number (47) that you had for your Atlanta study, actually. Furthermore, as I plainly stated in my book (Ring, 1984 , p. 29), there were a total of 111 NDErs who participated in this research, plus some control group subjects, so my overall sample was actually quite a bit larger than you reported. And, finally, concerning the methodological limitations of the study and my alleged lack of scientific caution, it is interesting to me that after quoting me partially on these matters, you failed to indicate what I wrote immediately afterward, so let me remind you here:

As a result of these methodological deficiencies, some of the conclusions I will draw will have to be taken tentatively from a scientific 
point of view. Perhaps they should be regarded as hypotheses to be more rigorously tested in subsequent research. I would encourage and welcome such investigations. (Ring, 1984, p. 30)

And as you yourself pointed out there have now been any number of investigations-to the best of my knowledge carried out in at least four different countries so far-that have in fact broadly confirmed the pattern of aftereffects I first delineated in Heading Toward Omega. Indeed, even in Light \& Death you described some of your own recent findings on such variables, using some the same measures I employed in Heading Toward Omega, and you reported the same results. You cannot have it both ways, Mike. You cannot impugn my research for its putative lack of objectivity and the in next breath concede that, with one possible exception (to be discussed in a moment), pretty much everybody else, including you, has found what I did!

In any case, after having raised doubts both about my motives and my research findings, you then zero in on one particular chapter of my book that deals with what I found having to do with changes in religious and spiritual orientations following NDEs. And it is here, Mike, where it seems to me you were guilty of some very blatant distortions and misrepresentations. Let me simply try to show you where and how, and take things one at a time.

You began by describing one of my questionnaires, the Religious Beliefs Inventory (RBI), and state that its findings "delivered a clear message to Ken: the near-death experience led people away from a [and then, seeming to quote me] 'more conventional (Christian) religious orientation'" (pp. 134-135).

Mike, I never said that. When I checked the page reference you cited, what I actually wrote was that agreement with certain items on the RBI would imply "a more conventional (Christian) religious orientation" (Ring, 1984, p. 145). You have therefore misrepresented me here.

Immediately afterward you cited a 1980 article of mine that I will return to later in another context in which $I$ had warned against a danger I even then perceived that the findings of NDE research could be, as it were, hijacked and used for propagandistic purposes by individuals with an obvious religious agenda. You then reproached me for apparently violating my own strictures by quoting this passage from Heading Toward Omega:

the real significance of the NDE here may not be simply that it promotes spiritual growth ... as much as the kind of spiritual growth it promotes. (p. 135, quoting from Ring, 1984, p. 144, and adding italics and ellipses) 
But, Mike, what exactly is the problem here? I am simply reporting a clear implication of the data from my study; I am not actually advocating anything, and I certainly have no religious ax to grind. There was nothing in my 1980 article that proscribed studying the spiritual or religious aftereffects of the NDE, but only using the NDE for hortatory purposes. You personally may have wished that the pattern of my data had turned out differently, but that is surely no reason to upbraid me personally.

But then you really appeared to get carried away in the next paragraph, which began, "A new religion was proposed" (p. 135). My goodness, just where did you find that in my text?! Of course, you did not-it simply is not there; you have invented it.

When I examined the skein of quotes you strung together to support this outlandish notion I could see what you had done. You had, first of all, taken the findings for a subset of NDErs, who espoused a more inclusive, spiritual orientation following their NDEs, and made it seem as if I were peddling this as "a new religion." Of course, this is absurd on the face of it, and reflects a persistent tendency on your part to confuse data with advocacy. By this logic, if I had discovered, say, that NDErs become believers in astrology afterward, you would perhaps jump to the conclusion that I was therefore endorsing astrology and recommending that it be incorporated as part of the new NDE-based religion. This kind of reasoning, once it is made explicit, is obviously preposterous.

This small paragraph then continued by averring that the new religion would evince (now apparently quoting me) "a marked shift toward Eastern religions such as Hinduism and Buddhism and spiritual universalism" (p. 135). Mike, I have searched in vain to try to find the source of that quote, which your notes say can be found on p. 158 of my book. But there is no such quote there. Where did you get it?

And that paragraph, seemingly still about the new religion I am urging, ended with a quote from the well known esotericist, Manly Hall, to the effect that in the end, we shall be "one congregation united in truth." I could not remember saying anything like that either-and it turns out I never did. The quote is actually from a book by Charles Flynn, as your endnotes made clear for the careful reader; but that would not be at all evident from the context of the paragraph, which seemed to be all about me, the avatar of the new NDE religion.

Your whole enterprise here, Mike, seemed to be so tendentious and to reflect such a patent desire to discredit my findings while "revealing" my apparently covert aim to foist a new NDE-based religion on my readers, that I can only shake my head at these gross distortions. You 
may have a target in your crosshairs, but I can tell you quite honestly, Mike, you are aiming at the wrong person.

Just to make it clear how far you were from seeing me aright, permit me to quote a passage (already cited by John Gibbs, but still most apposite here) from my recent book, Lessons from the Light (Ring and Valarino, 1998). It will serve to show you that I am not, after all, a religious prophet in blue jean garb:

This is not of course to suggest that the knowledge that stems from the NDE is meant to substitute for one's own faith or spiritual tradition. No, it's rather that the lessons from the Light are more akin to type O blood in transfusions-they are the "universal donor" to spirituality and religion in that they fit easily and well into a great variety of wellestablished spiritual traditions and world religions. And, more than that, as Carol Zaleski, a theologian who has written extensively on NDEs, has shown, the modern NDE has served not to undermine but to revitalize religious faith by providing fresh and compelling stories from ordinary people that ultimately coincide with perennial spiritual teachings from around the world. In this sense, the NDE generally serves to reinforce one's pre-existing faith by adding something compatible to it, not by competing with it. On the other hand, while the spiritual teachings of the NDE are obviously not meant to provide the basis of a new religion, much less a cult (!), it is certainly possible that they can offer to those who are not themselves religious or even to antireligious persons a point of view that furnishes a credible experiential basis governing moral conduct in the world. In the end, one might say there is only the magnificence and incomparable radiance of the Light. But what one makes of this Light is an individual matter. (Ring and Valarino, 1998, p. 302)

My protestations notwithstanding and coming, in any case, too late to restrain your wayward argument, you then compounded your recklessness by asserting in the next paragraph this utterly unfounded statement: "This call for a new world religion was welcomed by other NDE researchers" (p. 135). Well, Mike, as I have already made clear to you, there was no call, there was no "new world religion" propounded, and, accordingly, there was nothing to welcome. That charge, in the form of a single sentence, is a complete non sequitur. What you were really referring to is the fact that the researchers you then went on to nameMargot Grey, Charles Flynn, Phyllis Atwater, and Cherie Sutherlandin conducting their own studies found pretty much the same thing I did when they investigated religious and spiritual changes following NDEs.

Next came your "conspiracy theory," and that one, frankly, caused me both to wince and to chuckle at the same time, if that is possible. 
You wrote that as you were brooding about all this, you began to put 2 and 2 together, and there was apparently no doubt in your mind that it definitely added up to 4-specifically the four near-death researchers you had previously implicated as the welcoming committee for the new NDE religion. It turns out that I knew all of these people, they all were affiliated with assorted branches of IANDS, and I had furthermore befriended them in various ways. True enough, I guess. But there is the clear implication in your account of all this that my favors did not come for free. No, there was apparently some sort of sinister influencemy Svengali nature, I guess-that I was exerting over these people, fostering some kind of subtle conspiracy among us to slant the data so as to promulgate the new religious world view, as "new swords were forged to wage new religious wars" (p. 136).

But, Mike surely you must know this is pure hokum, tinged by a certain seeming paranoia. Will you at least listen to my view of this matter? Had you thought to write to me about this or to interview any of the researchers in question still living (Charles Flynn died some years ago), you would have quickly learned that your dark suspicions were baseless and the extent of my influence, if any, over my colleagues, greatly exaggerated.

To begin with, your conspiracy theory is funny. Take Phyllis Atwater, for example, whom I have known for as long as I have known you. Phyllis and I are still good friends, but she can tell you that rather than being kissin' NDE cousins, as you implied, we have had many differences over the years, the latest one surfacing in a recent issue of this journal (Atwater, 1998). And as far as having interviewed the same respondents, Phyllis, according to her latest book, has actually interviewed more than 3000 people, the vast majority of whom I have never met, much less talked to. I am sure Phyllis herself would just roll her eyes in amusement to learn how much you think I have influenced her data.

As for Margot Grey, although she did draw on some of the cases we had in our IANDS archives at the time she did a two-week internship with us there in the early $1980 \mathrm{~s}$, most of her respondents were from England. And far from being in cahoots with Margot, as you implied, let me remind you of the actual situation, which I disclosed when I wrote the foreword to her book, Return from Death (Grey, 1985):

As a result of her 'internship' with us, Margot and I became good friends and promised to keep in touch once she returned to England.

And so we did-after a fashion, but, since we were both continued to be very busy, our fashion was to write very occasional hasty notes, 
promising a 'real letter' when we found the (non-existent) leisure to write one. Not surprisingly, then, there was more warmth and good wishes in our correspondence than there was content. I knew that Margot was writing a thesis on NDEs - in due course I received a copy of it-but of Margot's larger writing projects I remained ignorant. In my own case, my life during the years that spanned our visits [I met her again in England in 1984] was primarily consumed with my new research ... which culminated in [Heading Toward Omega]. Nevertheless, as many authors tend to be, I was fairly closed-mouthed about my 'work in progress'; consequently, Margot herself knew virtually nothing about its substance or conclusions.

Thus, when we finally exchanged books in London, it was without any real knowledge of what the other had been up to....

[I soon discovered that] Margot had somehow contrived to write, entirely independently of my own research during these past three years, her own version of Heading Toward Omega! I could scarcely believe what I was reading in Margot's book-precisely because it was so close to what I had put into mine. (Ring, 1985, pp. ix-x)

So much for my purported influence, Mike. One might just as well say that Charles Darwin influenced Alfred Russell Wallace. We just independently were hearing the same thing from our respondents and simply wrote up what our NDErs were telling us as faithfully as we could. Much the same thing was true for the other researchers you name, and I could give you more supporting details there, too, but perhaps I have now made it obvious that the only conspiracy that existed was in your head.

It makes me wonder, though, why you went to such lengths to imagine it in the first place and then to make this case against me and these other researchers in print when you so easily could have checked the facts beforehand. I cannot help thinking that you had gotten this Machiavellian image of me in your mind, and began to detect its nefarious influence wherever you looked.

But before you think I am equally guilty of bashing you or unfairly questioning your motives, let me now acknowledge something that will perhaps surprise and even reassure you, at least about one point. When you ceased making ad hominem arguments and began talking about possible biases in sampling in near-death research, I find that I agree with you. Here, for example, you focused your attention on research suggesting a linkage between NDEs and belief in reincarnation, and argued that perhaps in different populations, as the data for your Atlanta sample, for instance, seemed to indicate, the relationship might vanish. It may also surprise you to learn that I personally have no particular stake in either affirming or denying the possible validity of 
reincarnation as a doctrine (though I certainly can understand why you would oppose it), and I am perfectly prepared to concur with you that there may well be regional, religious, and crosscultural differences in respect to its possible connection with NDEs. Indeed, I think you have very usefully brought to our attention the importance of reexamining some of the generalizations that have been widely accepted in NDE research thus far-and I, too, would urge that more studies like yours be undertaken to test the limits or even the validity of these generalizations.

The only thing I take exception to here is again a rather veiled implication that previous research was somehow slanted to produce a particular result or that other researchers made it clear to their respondents beforehand what their religious views were, whereas only your studies have been objective. You may not have intended to put it quite this way, but such statements convey a certain snideness that is just unworthy of you. Your methodological points are cogent enough without your having to resort to these gratuitous comments that are more suggestive of smears than reproofs.

Finally, since at the end of your chapter you returned, one last time, to the idea that some NDErs may after all be led to follow the road to Omega, perhaps this is the point for me to divulge something else to you that may surprise you. Indeed, I suspect it may well astonish you, particularly because it has been so long since we have actually sat down to have a face-to-face chat or even had its virtual equivalent by e-mail. But I can assure you that quite a few of my NDEr friends and colleagues have heard me say in recent years that I no longer am walking, much less leading the way, toward Omega.

Just to clue you in on this, let me simply quote from a letter I wrote a while back to a long-time NDEr friend of mine:

My views have changed quite drastically in some respects since I published Heading Toward Omega. In particular, I have foresworn my previous hypothesis about NDEs leading to "Omega" or anywhere else. I no longer think, and haven't for years now, that NDErs are part of a vanguard of folks leading us to the glory of higher consciousness. I won't deny that NDEs themselves can be transformative experiences for those who undergo them, but I do not think that such changes will spread like a kind of wildfire of consciousness to affect all of humanity.

As to why I wrote this little palinode and now reject the hypothesis I formerly so ardently espoused, there are various reasons. First, unlike you, I have remained pretty close to the NDE movement all these years, and in my opinion, it does not, as a whole, reflect the kind of atmosphere 
one would have imagined would follow from this kind of evolutionary impetus toward higher consciousness. Second, reading books such as Nicholas Campion's The Great Year (1994), Michael Grosso's The Millennium Myth (1995), John Perry's The Heart of History (1987), and Arthur Hastings' With the Tongues of Men and Angels (1991), among others, has persuaded me that the vision of a transformed humanity, shining like a golden promise just beyond the current historical epoch, has been, like a ever-receding desert mirage, beguiling civilization almost from its beginnings. At least in the West, it has been our recurrent archetypal dream of earthly-or even heavenly-salvation, and, as such, it is seemingly bred into our bone and woven into the fabric of our psyche. But a study of history only shows how common and pervasive this dream has been, and how much it has influenced our thinking, our philosophy, our religions, and our deepest longings. Very often, it is eloquently sung by the leading voices and glimpsed by the great visionaries of the day and thus broadcast to the many eager to believe that their age will be the one. History has shown, however, the disappointment that comes when invariably the dream does not manifest as fact, and must be rationalized away or, better yet, dreamed anew. Because the dream does not die, and it probably will not die. We in the West are bewitched by the siren call of evolution, and it continues to lure us on. As a myth, it is such a good story, and we do not seem to have eyes capable of seeing that it is only one possible story and that humanity's ultimate destiny may actually be a complete unknown.

A couple of years ago a well-known national politician, when confronted with the news that a long-concealed affair he had had when he was in his early 40 s was now public knowledge, tried to dismiss it as a "youthful indiscretion." This brought him even more derision, since a person in his early 40 s could hardly be considered a youth, but instead is a mature man.

Still, I am tempted to give a similar defense. I was in my mid-40s when I wrote Heading Toward Omega, and there is a lot in that book that I still stand by and am proud of. But my evolutionary speculations about NDEs leading toward Omega now seem to me to be the equivalent of my "youthful indiscretion." I am much older now, and I no longer glow with roseate optimism about humanity's future.

I still believe in NDEs, though. They are the real thing, whatever else might be said.

Well, I have even more to say about the rest of your book, Mike, but perhaps I have said enough for one letter. Indeed, you may feel that I have been unnecessarily harsh in some of my comments to you, but, 
believe me, it was not my intention to be unduly critical of you but only to try to set certain things straight. I think you know how much I have always respected and honored your work as a researcher, and I still do. In any case, I look forward to hearing from you in response to what I have already written here-and what I will say to conclude this essay, which will be addressed not just to you but again to a general audience-but I hope I have at least given you an alternate perspective from which to see your old friend and what he has been up to all these years.

\section{Religious Wars in the NDE Movement: A Personal Perspective}

For the remainder of this essay, since my focus will not primarily be on the book, Light \& Death, but on the more general issue of possible religious bias in near-death studies, my comments will no longer be directed to Michael Sabom in particular or need to take the form of an open letter. Instead, what I want to say is directed to all those persons who have an interest in trying to find a way to assure a legitimate and fruitful interplay between religious perspectives and the NDE.

When we early researchers first began our scientific studies of the NDE, we were of course under no illusion that we could -or even wanted to-keep vested religious interests from having a stake in our findings and making use of them in such a way as to reflect their own point of view. Indeed, all of us came to our work with a clear recognition of the religious and spiritual import of our then new discoveries about what it was like to die and what our NDErs were telling us about the insights they had gleaned from their experiences about such perennial religious concerns as life after death and seemingly heavenly realms.

What most of us hoped, however, was that we could keep religious bias from distorting our work or affecting our conclusions about the phenomenon of the NDE itself. Still, it was apparent to me almost from the outset that there were serious hazards here to be skirted, and in one of my first articles on NDEs, written for a short-lived newsletter of the Association for the Scientific Study of Near-Death Phenomena (Ring, 1980b), I tried to alert my colleagues to them:

... there is a dangerously narrow line between questions of religious import and those of religious doctrine. As soon as we step over that line, we run the risk of both unnecessary factionalism and hortatory research. Either development would be detrimental to the aims of our 
Association as I understand them. Therefore, it is a danger that we should be sensitive to before it threatens to undermine the achievement of the objectives we share. (1980b, p. 15)

What prompted me to write that article in the first place was my awareness that certain researchers with deep personal commitments to fundamentalist or evangelical Christianity were already beginning to appropriate or selectively use certain NDE cases in order to promulgate their own particular religious belief system and, by implication or even outrightly, attack those of others in a distressingly partisan way.

After reviewing some of these developments, I counseled that we should continue to investigate these experiences and the claims made for them with an open mind as carefully and systematically as possible, "precisely because their import is so enormous" (Ring, 1980b, p. 16), but then went on warn about the potential consequences of the trends in NDE research that already had begun to concern me:

Because of the deep commitment that some of us researchers have to our own religious or spiritual belief systems, we must always remain sensitive to the temptation of using our research data for propagandistic ends. If this were to be done with NDE research, it would not be much different, in principle, from past attempts to maintain and justify various forms of racism and sexism by making reference to "scientific data."

... If NDE research ends up simply providing new swords with which to wage old religious wars, I will regret very bitterly my involvement with this work. (Ring, 1980b, p. 16)

Those words were written 20 years ago, but from the current contentious climate within the field of near-death studies, these forebodings of mine seem eerily prophetic. To a great extent, what I feared would happen, has happened. As to my own reaction to these developments, perhaps I would want to moderate the adverbs I closed with, but it would not be inaccurate to say that when I view the NDE movement in this respect today, I feel disappointed, dismayed, and, even at times, appalled. To me, the original promise of the field of near-death studies has not only not been fulfilled; in significant ways, it seems to me to have been betrayed.

This is a strong condemnation, I know, and perhaps many readers will not share it, but let me at least provide a brief review of some of the developments I personally have witnessed over these two decades that prompt this dark assessment.

Once early research had established the broad outlines of the NDE and the media, particularly with the assistance of those of us in IANDS, 
had made the phenomenon its darling, many individuals or organizations with various religious leanings or spiritual perspectives began to show interest in the NDE. Even at the time, it was obvious that these developments reflected an interest either to annex, assimilate or, in the case of certain Christian fundamentalists, annihilate this newly emerging country of the NDE.

In addition to the religious mainstream in America, members of various smaller sects, such as the Swedenborgians, the Mormons, and the Baha'is latched onto the NDE while the fundamentalists, of course, fulminated against it. And not just Christians were drawn to the NDE flame, of course but Buddhists, too, especially certain Tibetan Buddhists. Beyond these, there were various more esoteric groups that soon made their move to appropriate some of the glory of the NDETheosophists, Anthroposophists (followers of Rudolf Steiner), students of $A$ Course in Miracles, kundalini networks, and New Agers of various stripes and shadings. In short, people representing the most diverse beliefs in contemporary American spiritual life (and I am mainly concerning myself here with the response to the NDE in North America) all sought to hitch a ride on the NDE wagon and, in some cases, to take over its reins.

But to forestall any misunderstanding at the outset, I was during this time intimately a part of these developments and in my own way helped to contribute to them. In virtually all the groups I have just mentioned-with the exception of the fundamentalist camp-I have deep good friends who have treated me with the utmost kindness, and I love many of them. I am certainly not attacking any of these groups or organizations with which I have these strong affiliative ties, and I have, almost without exception, enjoyed lecturing at their conferences. What I am writing about is the NDE movement as such, and specifically the kind of religiously-tinged and contentious atmosphere that now pervades it.

In any event, while the attacks of the fundamentalist near-death researchers and commentators continued during the 1980 s, it was, in retrospect, probably Betty Eadie's bestselling book, Embraced by the Light (Eadie and Taylor, 1992), that really fanned the flames of religious controversy in the NDE movement.

The enormous success and influence of Eadie's book took many of us in the NDE field by surprise, I think. I know I personally was astonished at its phenomenal sales and Eadie's almost meteoric rise to become for several years at least the leading charismatic spokesperson for the NDE, with many thousands of persons thronging to her talks. 
But it was not just the success of Eadie's book and her prominence as almost a kind of NDE personage that sparked the fires that soon raged within the NDE movement. Rather, it was a combination of factors including the circumstances of her NDE, how her book had come to be written in the way it was and who its sponsors were, as well as the reported content of her remarkably complex NDE that provoked a fusillade of charges against her. Of course, had her book simply been one more NDE autobiography with merely modest sales, few would have noticed or cared about what Betty Eadie said. It was her elevation to the role of a self-styled "NDE guru" that made her the target of such relentless fustigation.

First, because Eadie refused to provide the particulars about, or any documentation pertinent to, the claim she makes in her book for her 1973 NDE, which she wrote took place while hospitalized for a partial hysterectomy, her story was immediately challenged by those who took issue with what she related about it, particularly some of her theological conclusions. This matter has never been settled to the satisfaction of her critics, though I believe most persons who are familiar with her account give it credence, as I do.

Second, it eventually came out that Eadie, though having had exposure to several different religious traditions while growing up, was at the time of the composition of her book affiliated with the Mormon church-a fact that is nowhere stated in the book itself-and that the persons who bankrolled her book to begin with were also Mormons. At any rate, to anyone familiar with Mormon doctrine, there is much in Eadie's book that is consistent with its precepts and beliefs. In addition, I have heard it said by more than one informed source that there was a certain amount of "tinkering" with the text of Eadie's book on the part of Mormon scribes to make it conform more closely with Mormon doctrine, but that Eadie herself resisted these changes. I personally do not know if these allegations are true, only that they have added to the controversy about her book.

In support of these charges, one of her critics has offered the following brief:

...Embraced by the Light was originally marketed in the heavily Mormon areas of Utah, Arizona, and Nevada as a Mormon testimony. The first edition contained a one-page flyer entitled "Of Special Interest to Members of the Church of Latter-day Saints.” It recounted Eadie's conversion to Mormonism and her desire to convert others. The first edition also contained several obviously Mormon references that were altered in the mass-marketed version. In order to reach a wider audience, 
Eadie's book was published by Gold Leaf Press, which was formed out of-and continues to be owned by-the Mormon publishing house, Aspen Books. (Groothuis, 1995a, p. 22)

This apparent camouflaging of Mormon linkages in the NDE literature is a practice that is not confined to Betty Eadie's book, but crops up in other publications, too, as we shall shortly see.

But what really riled her critics, particularly those of evangelical persuasion, was that her NDE was in so many ways at variance with what is to be found in the Bible. As Douglas Groothuis, one, but not the harshest, of her foes asserted in an article published in a special issue of IANDS newsletter, Vital Signs, which was completely concerned with the theme of "The Christian Right and Near-Death Experience":

As I read the short but fantastic account of Eadie's experience "on the other side," I quickly discerned that the "Jesus Christ" to whom Eadie dedicated her book was not the same one the New Testament attests. (Groothuis, 1995b, p. 4)

And in Groothuis' book, pointedly entitled Deceived by the Light (1995a), he devoted two full chapters to detailing the many points on which Eadie and Biblical teachings deviate, ending with a chart extending over three pages listing 22 specific significant differences between Eadie's statements, presumably stemming from her NDE, and those of Scripture. Furthermore, as we shall discover, there are still those who feel compelled to challenge the "real identity" of the Jesus Betty Eadie claimed to have encountered during her NDE on the grounds that it does not accord with their conception of the "true Jesus."

Whatever the merit or relevance of these charges, the furor that engulfed Eadie's book helped to highlight another disturbing trend in the NDE movement involving the Mormon contribution to the literature on the subject.

From the very start of the field of near-death studies, and indeed even before its emergence as such, various Mormon scholars had fastened onto the NDE and similar experiences because, undeniably, they were remarkably consistent with Mormon teachings. And Mormon NDE scholars, particularly Arvin Gibson in a series of impressive volumes (1992, 1993, 1994, 1999), have certainly made some very important contributions to the literature on NDEs and their possible relation to religious teachings, all of which is unquestionably of value.

What is troubling, however, is when Mormon writers-unlike Gibson, who has always made his Mormon affiliation clear-are not forthcoming about their own allegiances and present their findings with an 
unacknowledged Mormon gloss. A case in point is a recent book, The Eternal Journey: How Near-Death Experiences Illuminate Earthly Lives (Lundahl and Widdison, 1997), by two widely published Mormon NDE researchers.

In her review of this book for this Journal, Jenny Wade (1999) commented on how this omission seriously detracted from the value of the book and called into question some of the authors' scholarship as well as their objectivity:

... the authors never state that their version of enlightenment, purpose, and meaning comes largely from a single source: The Church of Jesus Christ of Latter-day Saints (LDS or Mormons). Mormon ideology permeates the entire book, but identification with this organization is not apparent to the average reader who is the audience for this mass-market book. As much as I respect these researchers' previous work, their affiliation makes a difference, given the reason for writing The Eternal Journey. Like controversial NDEr Betty Eadie, Lundahl and Widdison's concealment of their ideological bias is in marked contrast to the straightforward stance of other Mormon writers, such as Brent and Wendy Top (1993) and Arvin Gibson (1992). The nature of this bias is particularly relevant in a work purporting to reveal the "reality" about the "meaning of life." The LDS ideology is so pervasive in the book that it deserves treatment here before the contents of the book can be properly reviewed. (Wade, 1999, pp. 51-52)

Then, after a brief but thorough exposure of the disproportionate "loading" of NDE cases from Mormon testimony and of devices that the authors employed in a seemingly deliberate effort at obscuration of their source materials, Wade, though she later went on to find value in the book, fairly excoriated the authors on this point:

Thus, the book, intended as an objective study of representative neardeath experiences from the general population conducted by objective scientists, is in fact a tract written by Mormons about mainly Mormons experiences. (Wade, 1999, p. 52)

It is this sort of disguised special pleading on behalf of a particular religious tradition that both irks and saddens me, and which, in my opinion, is helping to corrupt the values governing research in the field of near-death studies.

And it is not only researchers who are guilty of such practices, but even Mormon writers and publishers eager to capitalize on those interested in NDEs. For example, after attending the 1998 IANDS conference in Salt Lake City, I received an advertisement from a publishing house (whose name I will not divulge here) addressed "Dear IANDS 
Member," which went on to tell me:

While attending the recent IANDS convention in Salt Lake City, we saw some very interesting materials including various lists of useful books and studies on near-death studies and life-after-death experiences. We became aware that some of you may not have been introduced to several books published by our firm that contain very significant information which would be of value to you in your studies of near-death phenomena.

There followed several pages of promotional materials for five different books, both autobiographical and collections of cases of NDEs, all by Mormon authors, a fact that, oddly enough, was never mentioned at any point.

But I do not mean to pick on my Mormon friends-and I do have a number of deep friendships in that community. After all, the Mormons have had a hard enough time in their history gaining acceptance, and have paid more dearly for their beliefs than any American-based sect that I can think of. It is understandable why some of them might still feel a need to conceal their religious affiliation. It is just that when they - or any other group with a vested interest in the NDE-also conceal their ideological purposes from unsuspecting readers that I object. And besides, eventually, this will all come out anyway, and that will just make matters worse-as anyone who has followed American politics in the past few years will certainly be quick to concur.

Quite apart from some of the literature on NDEs, there have also been some events within the NDE movement itself that have made me personally quite uncomfortable during recent years. In particular I am thinking of some of the IANDS conferences I have attended where the degree of overt religious fervor I have observed has been off-putting to say the least.

Of course, in the literature on NDEs, particularly that stemming from fundamentalist critics, I am understandably always linked with IANDS, which is invariably pictured as some kind of hotbed of New Age intrigue. However, the facts of the matter are actually quite different than they are usually portrayed.

First, IANDS is an organization of astonishing diversity, with no party line, and it has undergone many changes over the years. Second, insofar as my own role in it is concerned, apart from helping to establish it, I have had no active involvement with it since 1983 when I resigned from its Board of Directors. A few years later, displeased with its overall level of service to its members at that time, I no longer was willing to see it housed in its original home, the Department of Psychology at the 
University of Connecticut, where I then taught. Shortly after that, its offices where relocated elsewhere, and my only formal connection with it was as an occasional speaker at its conferences. So my relationship with IANDS as such has actually been quite tangential for most of the past two decades.

In 1995, however, I was one of its speakers at its Hartford conference and afterward had occasion to respond to a letter from a professional colleague who had come to her first IANDS conference in order to present some of her own work on NDEs and related phenomena. As a newcomer, she had also been completely nonplused by the religious atmosphere she encountered, and wanted to know if her perceptions had been idiosyncratic. What follows is a portion of my reply to her:

Turning to your comments about a certain absolutist and "true believer" tone you discerned at the IANDS conference, you are right: It certainly was there and it is too complex and multi-faceted an issue to discuss succinctly in a letter. So here, let me content myself with just a few observations in response to the impressions you shared with me in your letter.

For some years I myself have been a bit dismayed at the almost religious or missionary tone at these IANDS conferences (although I attend them only occasionally - every three or four years or so). A great many attendees are experiencers and use the conference as a kind of over-sized support group. And it's understandable of course-providing an opportunity for a large bunch of NDErs to gather together in a safe and mutually selfaffirming environment releases a tremendous amount of pent-up energy and stirs vigorously the cauldrons of enthusiasm and proselytizing fervor (you should have been there the last day when Sunday morning exhortations were the theme of the day). Many of these persons are my friends, of course, and I don't mean to criticize them or sound a cavalier holier-than-thou note. But my tolerance for these excesses is limited and I sometimes have the feeling I am at a kind of revival meeting. (I should perhaps not exculpate myself from a certain complicity in this, however, since, according to Maurice Rawlings, I am the intentional founder of the heretical "Omega Religion.")

Of course, there are voices of restraint as well present at such meetings, and more than a few NDErs who are highly critical of the climate of these gatherings. But these people-and the sprinkling of scholars, academics, physicians and other professionals who are drawn to attend-do not set the tone for these IANDS conferences.

A few years later, in 1998, I again attended the IANDS conference, this time, as I have already indicated, in Salt Lake City. Given that this is the citadel of Mormonism, it would be expected that this conference might have more than the usual degree of religiosity, particularly because the Utah chapter of IANDS helped to arrange it and select its 
speakers. In fact, however, though this was in many ways one of the best, warmest, and most unified IANDS conferences I have ever participated in, it did not have an overly Mormonesque content. On the contrary, I think that the Utah chapter of IANDS bent over backwards to ensure a diversity of speakers and points of view. Nevertheless, I was again discomfited by the emphasis given to speakers who, however illustrious they may be, seemed to belong more in a pulpit than behind a podium at an IANDS conference.

As I wrote afterward to a long-time NDEr friend of mine who had been unable to come to this conference:

The tone of the conference, however, was quite religious, especially from the standpoint of the keynoters I heard. They were Howard Storm (with whom I had a very nice chat) and George Ritchie (ditto), whom I hadn't seen for 21 years. As you can imagine their talks were sermonesque in style, and the audience ate it up. All that was missing were the tents and the smelling salts. To be sure, their message was very ecumenical, but their zeal was not hidden. When I think back to what IANDS was in the beginning-a bunch of researchers, basically, who were curious about the NDE - and how it has now become largely a motley collection of persons pushing their own spiritual nostrums or religious ideologies, I am more than appalled.

Again, lest I be misunderstood, I want to make it clear that I personally have deep respect and personal affection for both Howard Storm and George Ritchie, both of whom have made enormous contributions to the field through their writing and speaking. And both of them have been kind enough to let me me interview them and publish portions of their experiences in my books. Of course, they have every right to tell their stories, which are inspiring in the extreme. But somehow the cumulative effect of hearing them at the IANDS conference made me wonder whether religious interests had now won the day and had started to dictate the agenda for an organization that had begun with such a different vision of its mission.

In view of the heavily Christian keynote addresses that dominated the 1998 IANDS conference, I could not help being amused by the contrasting impression that one of the most rabid of the fundamentalist critics of NDEs, Richard Abanes, has of the nefarious aims of this organization:

Unfortunately, the spirituality being propagated by most of these NDE researchers is patently nonchristian. In some ways, a new religion is forming ... because a majority of NDErs believe that heaven is a place of unconditional love and acceptance that awaits all men regardless of their beliefs. Adherents to this new faith of whom Betty 
Eadie is a clear symbol even have their own NDE sanctuary-the International Association for Near-Death Studies (IANDS). (Abanes, 1994, pp. 172-173)

Apparently, Abanes has not been attending the same IANDS conferences I have.

Of course the heart of the fundamentalist complaint about NDEs that Abanes gives such anguished voice to is easy to understand. When even Christian NDErs, such as the one I quoted in Heading Toward Omega, begin telling their audiences such blasphemous blanket assurances as this:

Nobody said to me, "What do you believe?" Nobody. The universe is not set up-I know this, my friends [laughter]-it is not fair to say if you believe in Jesus, you've got it made, and if you don't, you don't have anything made. (Ring, 1984, p. 157)

it is clear why these fundamentalist critics have no choice but to turn on their rhetorical hoses in order to douse the flames of this most heinous of heresies-the anathema of universalism, which seemingly promises a form of salvation to everyone, independent of belief, even to atheists.

Such embattled voices have been a part of the NDE movement, almost from the beginning, crying out against the universalistic tendencies of what they perceive to be the NDE mainstream and its theologically misguided heresiarchs, we researchers who would foist this pernicious doctrine on a world beguiled by the false promises of the testimonies we choose to quote.

One of the first of these critics is himself a near-death researcher, the cardiologist Maurice Rawlings, and the author of three books that purported to offer cases, especially of the "hellish" variety, that could be used as evidence in support of an evangelical Christianity (Rawlings, $1978,1980,1993$ ). Rawlings has made no attempt to conceal his polemical intent and the data from his widely-read books have often been used as weapons in the religious battles that have been fought on this front. In truth, however, Rawlings deserves to be credited with making an important contribution to the field of near-death studies because it was his initial work, whatever its limitations, that first made many of us aware of a type of NDE that had been overlooked, namely, those that were predominantly filled with frightening imagery and highly unpleasant emotions.

It is perhaps an irony that it was Sabom himself who in a masterful, thorough, and trenchant critique of the methodological weaknesses, shoddy scholarship, and blatant religious bias that permeated 
Rawlings' work as a whole exposed its utter unreliability as a source of data on NDEs (Sabom, 1996). On the basis of Sabom's sedulous examination of Rawlings' methods of data collection and analysis, it is clear not only that Rawlings was guilty of incredible sloppiness in reporting his and others' findings, but also that he apparently was not above manipulating his data in order to make it conform with religious doctrine. Sabom, at any rate, reported a number of examples of alleged first-person accounts of NDEs that were cited more than once in Rawlings' various books, but with significant differences in the wording and in other details of later versions, suggesting that they had been "reworked" to eliminate or smooth over certain theologically troubling inconsistencies. As Sabom, who has a reputation for being a meticulously scrupulous investigator himself, rightly commented:

... from a research standpoint, alteration of the patient's report-that is, alteration of the data-violates a basic principle of the scientific method by changing the material meaning of an otherwise unverifiable observation and casting doubt on the credibility of the whole account....Published as first-person, quoted accounts, these reports are supposed to be the words of the NDEr, not of Rawlings nor of his editor. If the verbatim nature of these accounts cannot be trusted, any meaningful evaluation becomes highly questionable. (Sabom, 1996, p. 202)

In concluding his lengthy review of Rawlings' most recent book, To Hell and Back (Rawlings, 1993), Sabom offered this final assessment of Rawlings:

He establishes himself before his audience as a cardiologist with impeccable credentials, a near-death researcher, and a committed Christian. Using these medical, scientific, and religious qualifications, he then presents the NDE as a glimpse of an afterlife and directly applies the Christian doctrine of heaven and hell to these experiences. This gridlike approach, however, poses problems to Rawlings in his interpretation of his and others' research when the type of person ... or type of near-death event ... does not jibe with the expected afterlife destination.... Rawlings confronts the data of others with authoritative statements substantiated with little or no data of his own and illustrated with anecdotal accounts that, over time, appear to have been altered to fit his own designs. (Sabom, 1996, p. 209)

Since Sabom, even in this book review, to say nothing of his latest book, makes it clear that he, too, is a committed Christian, it is obvious that his devastating critique of Rawlings cannot be dismissed by the latter's defenders on partisan grounds. On the contrary, it is really one of their own who has, in the name of scientific rigor, not religion, launched this attack. 
Curiously, it seems that Rawlings himself, even after reading Sabom's review, was not particularly disposed to deny his overriding purpose in writing his books in the way he did. As he was to admit to Sabom in a face-to-face conversation in February, 1994, there were inaccuracies in his data, but, he added, "he had been more interested in a correct Christian message than an accurate research report" (Sabom, 1998, p. 108). This is consistent with what Rawlings had told me, following a television program on which we had both appeared, in the late 1970s. At that time, as I mentioned in my own three-page critique of his early work in Life at Death (1980a), he said straight out that he could no longer "be impartial." His meaning was clear, and his subsequent work showed that he did indeed keep his vow.

Of course, this kind of guff does not exactly add anything of value to the field of near-death research; on the contrary, it only detracts from it by serving as ideological fodder-disguised as research-for the religious wars that elements of the conservative Christian community wish to wage on the NDE movement. In response, the chief weapon that we near-death researchers have used has been to write critiques of the sort that Sabom and I have offered. This has not, however, led to any real constructive dialogue. Instead pot shots just seem to be volleyed back and forth, in our own version of the Thirty Years War.

Recently, however, the arch enemy of fundamentalist Christian critics of the NDE-and the inadvertent founder of the NDE movement and still its most prominent spokesman-Raymond Moody himself has entered into the fray using a new weapon: humor. Since fundamentalists are not known for their sense of humor, and Raymond Moody, a physician by training, is, he decided to give them a dose of his own medicine. Indeed, in his most recent book on NDEs, The Last Laugh (1999), the patriarch of the NDE unleashed his heavy ammunition in the form of a broad satirical attack on those he mockingly calls the "fundaChristians," an odd term whose derivation he will shortly explain:

They are the goshawful deadfannies, stiffs, bores, nuisances, uptight dogmatists, broken records, and wet blankets, the fundamentalist Christians, Religious Right, Bible Brigade, "JAY-sus"-Sayers, Brimfire and Hellstoners, Swaggartists, Falwellers, Bakker-Boosters, Pat Robertsonians, or whatever you would call them. Out of politeness, I deem them "funda-Christians." By back-clipping, the nickname kindly avoids calling attention to one of their most conspicuous shortcomings, because it doesn't even mention one of the very qualities in which so many of them are weak or deficient....

The funda-Christians have been charging me with demonic espionage ever since I went public with my findings about near-death 
experiences in 1972. Beautiful, bliss-and-love-filled near-death experiences of a bright light upset funda-Christian experts ... because they suspect the light-and-love-filled ones may be Satan conducting an undercover operation. Grim, ghastly, flame-filled, agony-and-sufferingridden, Hellish near-death experiences, in which the people who almost died toasted in torment, are okay by the funda-Christian authorities, though. The infernally-oriented, Satanically-focused, funda-Christian, near-death experience experts enjoy finding cases of Hellish experiences. They can use cases like that for writing knowledgeably about Satan, demons, sinners in torment, and eternal damnation. Some of these men write mighty amusing treatises, and I wholeheartedly recommend their works.

A man named Dr. Ravings, if I recall his name correctly, is a main funda-Christian doctor-expert on near-death experiences. This specialist in close-call perdition is on the look-out for terrifying infernal, perimortal visions. I'm one of the most enthusiastic fans of Dr. Ravings' writings. (Moody, 1999, pp. x-xi)

This sort of outrageous nose-tweaking levity went on for several more pages, though Moody's book actually eventually became, in part, a serious critical study of some of the excesses of the NDE movement that have particularly rankled him. His poking fun at his conservative Christian critics and researchers like Rawlings will probably do nothing but inflame them and will certainly not contribute anything to the NDE movement apart from a few cheap laughs. But it does reflect, I think, the underlying religious enmity that has come to pollute the air of the NDE movement these days, just as our national political scene has been coarsened by rancorous and increasingly mean-spirited partisanship in recent years.

It is perhaps unfortunate but significant that it is precisely in this rather poisoned and polarized atmosphere that Sabom's new book has made its appearance. From this perspective, it is a book that in many ways reflects the distinctive fraught tensions of this increasingly dysphoric period in the history of the NDE movement. And if one contrasts the polemical tone and content of this book with Sabom's earlier Recollections of Death, it also can serve to reveal how much of a shift there has been from the early days of the field of near-death studies, which was dominated by scientifically oriented research, to today, where the body of the NDE, like some sort of sacred relic or corrupted corpse, is fought over by warring parties either for rights of possession or unceremonious burial.

I do not have the heart, the interest, or the space to try to review here the final chapter of Sabom's book, entitled "The Bible and the NearDeath Experience," where he gave his overall assessment of the nature 
and meaning of the NDE by openly acknowledging that he meant to use the Bible as his ultimate hermeneutical authority. Suffice it to say that, as an avowed evangelical Christian, Sabom's interpretations are all doctrinally driven and in line with his theological beliefs. There are all the expectable warnings about dabbling with psychic matters, testing the spirits, Satanic deceptions with demons posing as beings of light or even masquerading as the Christ (Sabom, like other fundamentalist critics, strongly implies that this was the case for such celebrated NDErs as Betty Eadie and George Ritchie)-in short, the whole familiar litany of conservative Christian exhortations against anything that might deviate from their understanding of Biblical truth or threaten to undermine it.

In the end, the world according to Sabom seems to be divided into the usual absolute categories: The saved and the damned-and the damnable. Although he did not mention it in his text, in the group of NDErs that Sabom himself identified with-those he called Conservative Christians-86 percent agreed with the statement, "Nonacceptance of Jesus Christ as Lord and Savior condemns one to hell in the afterlife." There you are. I suppose that people like me, most of my friends and family are not likely to receive invitations to their garden parties either. To me, it is particularly dispiriting that although we are supposedly living in a postmodern age, we still find statements like these coming from the cream of Sabom's NDErs. Why do I have the feeling that instead I am back in Tertullian times, listening to him rage against the Gnostics? Perhaps I need to remind myself that I am still living during an era when fundamentalists in another country have kept Salman Rushdie under a death sentence for more than a decade. I am lucky, I guess-here, I am only told that I will rot in hell because I do not accept Jesus Christ as my personal savior and for my part in perpetuating the universalist heresy.

From this long, if admittedly partial, summary of the religious wars now pervading the NDE movement, I suppose it will be evident why, when John Audette and I were reminiscing about the beginnings of our work and what motivated us then, we found the present situation so disheartening. Not our best hopes but our worst fears seem to have been borne out: The heat of religious controversy among the would-be colonizers and foes of the NDE has, at least for now, seemingly eclipsed the Light of the NDE itself.

Nevertheless, despite everything, perhaps I am still enough of a congenital optimist to cherish a faint if possibly unrealistic hope that the NDE movement is just in the midst of a sorry phase that will pass, 
even as an eclipse of the sun will eventually vanish leaving its light to shine again on all the world. So to conclude this piece as well as to give expression to this vision of a renewed ecumenical spirit in the NDE movement, let me return to my Mormon friends, since I have picked on them so much here, in order to show how one of them has reminded us that there is a way that potentially can embrace us all, not by uniting us in belief but by making us aware of what the real religious significance of the NDE may be.

I suppose it might come as a bit of a shock to the readers of this article to learn that after all my inveighing against the distressing incursion of tendencious religious thought in the NDE movement I have recently written a complimentary foreword to a book by the prominent Mormon NDE researcher, Arvin Gibson. Furthermore, in this book, The Fingerprints of God (Gibson, 1999), Gibson made no bones about his Mormon affiliation and indeed devoted the last third of his book to a lengthy discussion of the relationship of the NDE to Mormon history and doctrine. (And this, incidentally, is not the only foreword I have written for NDE-based books by writers with an openly declared allegiance to their own religious tradition.) I mention this chiefly to make it clear that of course I have no objection in principle to books on NDEs written from a religious point of view. Rather, as I trust this article has made plain, what galls me is when their religious investments are concealed or when the theological tail begins to wag the NDE dog.

In any case, one of the passages I particularly appreciated in Gibson's book related to something that Howard Storm, the NDEr who spoke with such passion at the 1998 IANDS conference I have already mentioned, has said he learned from his own NDE. To quote now from my foreword:

Howard has become quite celebrated in NDE circles because of having had a most unusual NDE, the result of which was that he ceased being an atheistic art professor and became in time a very dedicated and effective pastor of the United Church of Christ. What is especially important for us in this context-and this is the story Arvin himself tells in full in his book, to striking effect-is that Howard, too, during his NDE was led to ask his spiritual guides the same question that prompted Joseph Smith to initiate his religious quest in 1820: What was the true religion?

Howard of course was not destined to be a prophet, but "only" a pastor; still, it is very instructive to consider the answer he received, which was, "The best religion is the religion that brings you closest to God." (Ring, 1999, p. xv)

This, to me, is the real keynote we should be sounding in our religiously oriented study of the NDE because it rings out in such a way 
as to embrace everyone and every creed. I do not share the same belief system as Arvin Gibson, Howard Storm, or Michael Sabom, but all four of us seem to agree that the NDE shines with the Light that ultimately leads us back to God. What does the rest really matter when the NDE is viewed from that standpoint? And even the atheist, who would deny God, when confronted with the Light cannot deny his or her own experience. Even so, what does it matter how he or she regards it? Each near-death experiencer, regardless of his or her belief, or lack of it, is the ultimate authority on the personal significance of the NDE he or she has undergone. Why should any of us presume to make the judgment about or pronounce on its authenticity?

Since this article was intended only as a personal expression of my own views, as stimulated by Sabom's book, I would like to end it by harking back to what I wrote in my 1980 article, when the field of near-death studies was just beginning, in order to urge a return and rededication to the vision many of us then shared. Although I concede these lines may still appear to betray my own bias toward an universalistic understanding of the NDE, I would like to ask that they be now be read and understood in the ecumenical spirit of the observation by Howard Storm that Arvin Gibson has so helpfully called to our attention. Thus, let the closing words of that early paper serve as mine for this one, and at the same time express my heartfelt wish for a new and harmonious era in the NDE movement:

... I prefer to believe that we can remain open to the religious and spiritual implications of near-death research, neither excluding any possibilities nor rushing to self-serving religious conclusions. In this respect, I think we would do well to emulate the example of many neardeath survivors themselves who seem to emerge from their experience with a heightened spiritual orientation which can embrace all forms of religious worship without necessarily espousing any one form for themselves. If near-death research has definite spiritual overtones, as I believe it does, I hope that it will ultimately promote the cause of religious diversity rather than religious divisiveness. (Ring, $1980 \mathrm{~b}$, p. 16)

\section{References}

Abanes, R. (1995). Embraced by the light and the Bible: Betty Eadie and near-death experiences in the light of Scripture. Camp Hill, PA: Horizon Books.

Atwater, P. M. H. (1998). Concerning anesthetically-induced frightening NDEs [Letter]. Journal of Near-Death Studies, 17, 138-141.

Campion, N. (1994). The great year. London, England: Arkana.

Eadie, B. J., and Taylor, C. (1992). Embraced by the light. Placerville, CA: Gold Leaf Press. Gibbs, J. C. (1999). [Review of Light at death]. Journal of Near-Death Studies, 18, 117-127. 
Gibson, A. S. (1992). Glimpses of eternity. Bountiful, UT: Horizon.

Gibson, A. S. (1993). Echoes from eternity. Bountiful, UT: Horizon.

Gibson, A. S. (1994). Journeys beyond life: True accounts of next-world experiences. Bountiful, UT: Horizon.

Gibson, A. S. (1999). The fingerprints of God. Bountiful, UT: Horizon.

Grey, M. (1985). Return from death: An exploration of the near-death experience. London, England: Arkana.

Grosso, M. (1995). The millennium myth: Love and death at the end of time. Wheaton, IL: Quest.

Groothuis, D. (1995a). Deceived by the light. Eugene, OR: Harvest.

Groothuis, D. (1995b). To heaven and back? Vital Signs, 14(4), 4-7.

Hastings, A. (1991). With the tongues of men and angels: A study of channeling. Fort Worth, TX: Holt, Rinehart and Winston.

Lundahl, C. R., and Widdison, H. A. (1997). The eternal journey: How near-death experiences illuminate our earthly lives. New York, NY: Warner.

Moody, R. A. (1975). Life after life. Covington, GA: Mockingbird Books.

Moody, R. A. (1999). The last laugh: A new philosophy of near-death experiences, apparitions, and the paranormal. Charlottesville, VA: Hampton Roads.

Perry, J. (1987). The heart of history. Albany, NY: State University of New York Press.

Rawlings, M. (1978). Beyond death's door. Nashville, TN: Thomas Nelson.

Rawlings, M. (1980). Before death comes. Nashville, TN: Thomas Nelson.

Rawlings, M. (1993). To hell and back: Life after death-Startling new evidence. Nashville, TN: Thomas Nelson.

Ring, K. (1980a). Life at death: A scientific investigation of the near-death experience. New York, NY: Coward, McCann and Geoghegan.

Ring, K. (1980b). Psychologist comments on the need to keep religious bias out of neardeath research. Anabiosis [East Peoria], 2(1), 14-16.

Ring, K. (1981). [Review of Recollections of death]. Vital Signs, 1(3), 8-10.

Ring, K. (1984). Heading toward omega: In search of the meaning of the near-death experience. New York, NY: William Morrow.

Ring, K. (1985). Foreword. In M. Grey, Return from death: An exploration of the near-death experience (pp. ix-xii). London, England: Arkana.

Ring, K. (1999). Forward. In A. S. Gibson, The fingerprints of God. Bountiful, UT: Horizon.

Ring, K., and Valarino, E. E. (1998). Lessons from the light: What we can learn from the near-death experience. New York, NY: Plenum/Insight.

Sabom, M. (1982). Recollections of death: A medical investigation. New York, NY: Harper and Row.

Sabom, M. (1996). [Review of To hell and back: life after death-Startling new evidence]. Journal of Near-Death Studies, 14, 197-209.

Sabom, M. (1998). Light \& Death: One doctor's fascinating account of near-death experiences. Grand Rapids, MI: Zondervan.

Wade, J. (1999). [Review of The eternal journey: How near-death experiences illuminate our earthly lives]. Journal of Near-Death Studies, 18, 51-57. 